\title{
An individually randomized controlled trial to determine the effectiveness of the Women for Women International Programme in reducing intimate partner violence and strengthening livelihoods amongst women in Afghanistan: trial design, methods and baseline findings
}

Andrew Gibbs ${ }^{1 *}$ D, Julienne Corboz ${ }^{1}$, Mohammed Shafiq ${ }^{2}$, Frozan Marofi ${ }^{2}$, Anna Mecagni ${ }^{3}$, Carron Mann ${ }^{3}$, Fazal Karim ${ }^{2}$, Esnat Chirwa ${ }^{1}$, Charlotte Maxwell-Jones ${ }^{4}$ and Rachel Jewkes ${ }^{1}$

\begin{abstract}
Background: Intimate Partner Violence (IPV) is the most common form of violence in conflict and post-conflict settings, but there are few evaluations of interventions to prevent IPV in such settings.

Methods: The Women for Women International (WfWI) intervention is a year-long combined economic and social empowerment intervention for marginalized women survivors of conflict. Primarily, it seeks to support women to achieve four key outcomes: women earn and save money; women improve their health and well-being; women influence decisions in their homes and communities; women connect to networks for support. The organization recognizes Violence Against Women and Girls (VAWG) as a significant barrier to women's empowerment and expects to see reduction in VAWG, and specifically IPV, as part of building women's social and economic empowerment. This program is being quantitatively evaluated through an individually randomized control trial amongst women in Afghanistan, with a 24-month follow up. A comparison of baseline characteristics of participants is also included as well as a discussion of implementation of the baseline research.

Discussion: There is a high demand amongst Afghan women for such interventions, and this posed challenges in completing the randomization and baseline. In addition, the complex security situation in Afghanistan also posed challenges. However, despite these issues, recruitment was successfully achieved and the arms were balanced on socio-demographic measures. The evaluation will contribute to the limited evidence base on interventions to prevent IPV in conflict-affected settings.
\end{abstract}

Trial registration: NCT03236948. Registered 28 July 2017, retrospectively registered.

Keywords: Afghanistan, Trial, Economic empowerment, Gender transformation, Intervention, Baseline

\footnotetext{
*Correspondence: andrew.gibbs@mrc.ac.za

${ }^{1}$ Gender and Health Research Unit, South African Medical Research Council,

Pretoria, South Africa

Full list of author information is available at the end of the article
} 


\section{Background}

In conflict and post-conflict settings, intimate partner violence (IPV) is the most common form of violence that women experience, despite non-partner sexual violence and other forms of violence being more often focused on [1, 2]. There is also increasing evidence that high rates of IPV are likely to continue after conflict has ended [3-7] and are fueled by the enduring impact of conflict [8]. IPV and other violence experienced by women and girls need to be prevented in conflictaffected settings, as much as this must be done in more peaceable contexts.

Until fairly recently, reducing IPV among conflictexposed populations was not very high on the peacebuilding or development agenda. As a result, few interventions to reduce IPV have been tested in these settings [1]. The interventions tested have generally combined economic empowerment of women with or without some form of other elements, including gender-focused ones. In conflict-affected communities in Uganda, a women's economic empowerment intervention showed no impact on IPV experience, but the addition of a short male partner involvement intervention showed some positive (but non-significant) improvements in relationships [9]. Similarly, in Afghanistan, an economic-only intervention showed increases in women's economic participation and mobility, but showed no impact on women's status within the home [10]. In post-conflict Ivory Coast, a women's savings group intervention had gender dialogue sessions added to it, which showed positive trends in outcomes [11]. The positive effects of interventions combining gender transformative/social empowerment components with economic interventions is reflected in the wider IPV prevention research in nonhumanitarian settings $[12,13]$. More research is needed to develop interventions that are appropriate and effective in challenging contexts.

Afghanistan has experienced more than four decades of conflict and has a deeply patriarchal gender regime based on conservative cultural practices and conservative Islamic interpretations of men's and women's roles. Women have very little power, violence against women and girls is endemic, and harmful traditional practices are widespread. These include honour killings, early and forced marriage of girls [14], bride price (walwar or sherbaha ${ }^{1}$ ), baad (the giving of girls to a disputant party to settle a debt or conflict) and badal (women and girls exchanged between families for marriage). Women's options for leaving abusive relationships are highly constrained: women's freedom of movement and access to social safety nets are highly limited; and women who 'run away' are regarded as having attempted to commit the 'moral crime' of zina (which implies either adultery or having sexual relations with somebody out of wedlock) regardless of whether there is any evidence or not. Women survivors of sexual violence have also been accused of committing zina. If caught, women would be punished either through the formal system (jail) or through informal systems and there have been many reports of women being abused at the hands of mobs. Women have also been subjected in abusive investigatory techniques by the police, including (scientifically invalid) 'virginity testing.'

The use and acceptability of violence against women and girls in Afghanistan is widespread. The 2015 Afghanistan Demographic and Health Survey (AFDHS) found that $80 \%$ of women and $72 \%$ of men (for both groups, married and aged 15 to 49 ) agreed that it was justified for a woman to be beaten by her husband in at least one of five circumstances, particularly if a woman goes out of the house without telling her husband [15]. An early estimate on women's experiences of IPV in Afghanistan from research conducted with 4700 women in 16 (of 34) provinces found that $73.9 \%$ of women reported psychological IPV, $52.4 \%$ of women reported experiencing physical IPV ever, and $39.3 \%$ of women experienced physical IPV in the previous year [16]. The study found risk factors for experiencing IPV included being in a forced marriage, being in a polygamous marriage, being under age 15 years old and married, having gender inequitable attitudes, and living in a rural area [16].

More recent data from the 2015 AFDHS indicates that $56 \%$ of ever married women aged 15 to 49 reported having ever experienced any type of spousal violence (emotional, physical or sexual) and 52\% reported having experienced at least one of these forms of violence in the past 12 months [15]. Spousal physical IPV is the most common type of violence, with $51 \%$ of women reporting ever having had experienced physical violence (e.g. being slapped, pushed or shaken, punched, kicked, dragged, choked, burned or attacked with a weapon, or having their arm twisted or hair pulled). Of those women having reported spousal physical violence in the past 12 months (45.8\%), 26\% sustained subsequent physical injuries [15]. Fewer women reported ever having experienced any kind of spousal emotional violence (37\%), or sexual violence (7\%), though it is likely sexual violence is under-reported. The Afghanistan DHS found a wide range of risk factors for spousal violence, including women being employed but not being paid in cash (i.e. receiving goods or other non-cash earnings), lower education of both women and their spouses, husbands' controlling behaviour, a family history of domestic violence, and living in a rural area [15]. There was also wide variation by Province in the prevalence of lifetime IPV, ranging from $6 \%$ in Helmand province and 7\% in Badakhshan Province, to $92 \%$ in Ghor and Herat Provinces [14]. 
This paper describes the methods for an evaluation of an economic strengthening and social empowerment intervention, developed and used for 15 years by the international non-governmental organization Women for Women International (WfWI) in Afghanistan. We report the methods in terms of the SPIRIT (Standard Protocol Items: Recommendations for Interventional Trials) 2013 Checklist [17], and compare baseline characteristics of participants. The trial is an individually randomized control trial with endline follow up 24 months after baseline.

\section{Methods/design}

The trial is conducted as part of the "What Works To Prevent Violence? A Global Programme on Violence Against Women and Girls (VAWG)", funded by the UK Government's Department for International Development (DFID). ${ }^{3}$ The Global Programme is funding research on 16 interventions in 13 countries to assess the effectiveness of the interventions in prevention of VAWG. The work is conducted in Africa, the Middle East and Asia.

This trial is being led by the South African Medical Research Council working through local research agencies in Afghanistan, and the intervention is being delivered as per normal practice by WfWI.

\section{Objectives}

The aim of this study is to evaluate the effectiveness of the Women for Women International (WfWI) intervention in reducing IPV experienced by married Afghan women and improving their mental health.

1. The primary objective is to determine whether exposure to the WfWI intervention is effective in reducing experience of intimate partner violence and improving the mental health of women in the programme.

2. The secondary objective it to determine whether exposure to the WfWI intervention is effective in improving women's income and savings, and creating more equitable gender attitudes, including reducing the acceptability of IPV.

\section{Trial design}

The study is a two-arm, individually randomized controlled trial. Intervention arm participants receive the WfWI intervention (i.e. WfWI's core programme), a combined social empowerment and livelihoods strengthening intervention, alongside a US\$120 cash transfer over 12 months (US\$10 per month). This cash transfer is a standard part of WfWI's core programme to cover training-related expenses, contribute to household needs and help women to start to build savings. Control arm participants are given $\$ 10$ per interview to motivate assistance in the study and as reimbursement.

\section{Sample size}

A pilot study was conducted in August 2016 with 100 women who were already part of the WfWI intervention to assess the questionnaire, as well as provide an estimate of physical IPV experience in the past 12 months. We found many of the women already enrolled in the WfWI intervention were not currently married, in fact only 37/100 were. Among these, past year physical IPV prevalence was $32.4 \%$ and past year severe IPV prevalence was $27 \%$. At the time, this corresponded to published data, which estimated $39.3 \%$ of women had experienced past year physical IPV [16].

We used an assumption of seeing an effect size of 0.3 difference between the 12 month prevalence of physical IPV at endline in the control and intervention arms. This is the effect size seen in several recent evaluations of effective violence prevention interventions [18, 19]. We assume that the 12 month control arm IPV prevalence will be $32 \%$ and severe IPV $27 \%$. Using Stata, with power set at .80 and alpha at 0.05 , sample size per arm was estimated to be 337 for past year physical IPV, and 422 for past year severe physical IPV. Based on our calculations for the percentage of women recruited into the intervention being currently married, and the potential loss to follow-up, the target number of participants was 1477.

\section{Study setting}

The provinces and districts selected for the research were those in which WfWI planned to work in 2016 and 2017 during the recruitment phase. These were established in enrollment plans for the intervention designed at the start of each year, and the research was fitted in around these plans. As per previous years of implementation in Afghanistan, communities in which WfWI implemented their programming were selected through community level assessments, and coordination with district government authorities, to ensure the most appropriate communities would be included. Security concerns also factored into selection of communities, with the aim of ensuring security for WfWI staff members as well as the intervention participants. Due to the introduction of the RCT in 2016, additional criteria for community selection included ensuring a sufficient number of women were eligible to enroll in both the intervention and control arms of the study.

The evaluation was conducted in two provinces, Kabul and Nangarhar. In Kabul, three districts were selected and in Nangarhar, two districts. WfWI was working in additional provinces at the time but we chose to work in two provinces for the study design for pragmatic reasons. In each district, a central village was identified with a training centre from which WfWI could run the intervention. Depending on the 
size and structure of the village, women also came from surrounding areas.

\section{Recruitment}

Once communities are selected by WfWI, WfWI field staff undertook community mobilization activities to explain the objectives of the programme and the research to community and religious leaders and obtain their support for implementation. Information was then shared in villages through community meetings and Friday Mosque prayers. Women interested in participating were asked to assemble on a scheduled date and location.

Women were individually recruited into the study. WfWI staff members explained WfWI's core programme, while research staff members explained the research study and randomization process. Participants were screened for eligibility before being enrolled into the study.

\section{Eligibility criteria}

The eligibility criteria for the study mostly followed the entry criteria for WfWI. The regular selection criteria for the WfWI intervention were that participants should be at the lowest economic level possible, earning less than a US $\$ 1.25$ a day, they should be unemployed, not in school and not involved in a similar programme. Women incapacitated due to mental illness or very severe disability would not be eligible for the intervention, as they otherwise would not be able to fully benefit by engaging in the training sessions (e.g. if blind they would be unable to observe the training materials, or if deaf they would be unable to hear the content of the training) or by doing income generating work. Women should be willing to participate in the programme and attend all training classes and not have previously participated in the programme. Preference was given to women who are mothers or heading households, irrespective of marital status. Women were encouraged to secure support from family members for their involvement to better facilitate their participation, although this was not always possible.

Two additional criteria due to the research were added: 1) restricting the age of women to 18 and 45 years due to issues of consent for those under 18 year olds; and 2) increasing the proportion of currently married women in the sample than is general WfWI practice because in Afghanistan, it is only feasible to ask IPV questions of currently married/previously married women. The age restriction also reduced the likelihood of mother-in-laws being recruited into the study alongside their daughter-in-laws. (A pilot study found that having two members of the same household in the study led to concerns about maintaining privacy about the study).

\section{Intervention}

The intervention has been developed and refined since 1993 by WfWI and is an approach to intervening in complex settings in alignment with the needs of women who have been denied access to education, have been negatively affected by conflict and who seek inclusion and recovery., also referred to as WfWI's core programme, has been implemented by WfWI in eight countries. The theory of change for the intervention is shown in Fig. 1 and is focused specifically on reducing IPV.

In all the villages, activities are delivered by locally hired staff from the community who speak local dialects. Staff use a range of methods to deliver the curriculum including storytelling, role-playing, or discussion questions. Due to the typically very low levels of literacy of participants in Afghanistan, trainers and staff tend to use verbal methods. Sessions are approximately $90 \mathrm{~min}$ long, delivered over a year, to adapt to women's availability and constraints on their time (such as care work).

Component 1: Informational Training: critical information about savings, health, rights, and networking is delivered through key modules as part of the year-long programme:

- The value of women's work: This module focuses on supporting women to overcome stereotypes and inequities that prevent them from gaining economic self-sufficiency. This module educates women about division of labour, household financial management, and the different types of opportunities for income generation that are available to them.

- Health, wellness and violence against women. This module focuses on building women's understanding of: health as an asset; health as a human right; health as an essential criterion to undertake other productive activities; women's bodies and how to care for them; prevention, treatment, and management of key health issues; safe space to discuss sensitive topics, including conflict, sexual and gender based violence; and referrals to health services.

- Rights, family and community decision-making. This module covers human and legal rights, and what women as individuals- and as a group - can do to exercise their own rights in their families and communities. It addresses women and family law including inheritance, control of assets, marriage, divorce and child custody, and domestic violence and rape.

- Social networks and safety-nets. This module covers the value of women working together in groups and/or in social networks; building effective networks; planning for group advocacy; managing leadership issues; negotiation and conflict management (within the household). 


\begin{tabular}{|c|c|c|c|c|c|c|}
\hline \multicolumn{7}{|c|}{ What's the problem? } \\
\hline \multicolumn{7}{|c|}{ Physical intimate partner violence is common amongst married women in Afghanistan } \\
\hline \multicolumn{7}{|c|}{ What are the risk factors/drivers of the problem? } \\
\hline $\begin{array}{l}\text { High levels of poverty } \\
\text { and conflict related } \\
\text { trauma increasing } \\
\text { stress in hous eholds } \\
\text { and reinforcing gender } \\
\text { inequitable attiudes }\end{array}$ & $\begin{array}{l}\text { Women's lack of } \\
\text { economic } \\
\text { independence }\end{array}$ & $\begin{array}{c}\text { Gender inequitable } \\
\text { attitudes and practices } \\
\text { within the household that } \\
\text { reinforce male power and } \\
\text { control }\end{array}$ & $\begin{array}{l}\text { Community level } \\
\text { norms and attitudes } \\
\text { that support } \\
\text { women's } \\
\text { subordination }\end{array}$ & $\begin{array}{l}\text { Poor mental } \\
\text { health of } \\
\text { women }\end{array}$ & $\begin{array}{l}\text { Women's lack of } \\
\text { social networks } \\
\text { for support/ } \\
\text { isolation }\end{array}$ & $\begin{array}{l}\text { Lack of education, } \\
\text { including around } \\
\text { women's rights }\end{array}$ \\
\hline \multicolumn{7}{|c|}{ What types of interventions are needed to address the risk factors/drivers? } \\
\hline \multicolumn{2}{|c|}{$\begin{array}{l}\text { Economic strengthening interventions } \\
\text { focused on strengthening women's } \\
\text { economic position }\end{array}$} & $\begin{array}{l}\text { Interventions to } \\
\text { strengthen women's } \\
\text { rights, transforming } \\
\text { gender norms, building } \\
\text { women's social power }\end{array}$ & $\begin{array}{l}\text { Community level } \\
\text { intereventions that } \\
\text { work with men to } \\
\text { transforming } \\
\text { attitudes }\end{array}$ & \multicolumn{2}{|c|}{$\begin{array}{c}\text { Group-based social support; } \\
\text { referral }\end{array}$} & $\begin{array}{l}\text { Information and } \\
\text { awareness about } \\
\text { women's rights; } \\
\text { numeracy training }\end{array}$ \\
\hline \multicolumn{7}{|c|}{ What are the specific aspects of the intervention to be included? } \\
\hline \multicolumn{2}{|c|}{$\begin{array}{l}\text { Women trained on: vocational training; } \\
\text { savings support, including a cash } \\
\text { transfer; numeracy training }\end{array}$} & $\begin{array}{l}\text { Women's rights training; } \\
\text { health training; support } \\
\text { around women's position } \\
\text { in households }\end{array}$ & $\begin{array}{l}\text { Men's Engagement } \\
\text { Programme where } \\
\text { necessary at the } \\
\text { community level }\end{array}$ & \multicolumn{2}{|c|}{$\begin{array}{l}\text { Women's groups established, } \\
\text { with group-based support } \\
\text { structures; referral for support to } \\
\text { services }\end{array}$} & $\begin{array}{l}\text { Numeracy training; } \\
\text { women's rights } \\
\text { education }\end{array}$ \\
\hline \multicolumn{7}{|c|}{ Envisaged Medium Term impacts? } \\
\hline $\begin{array}{l}\text { Improved hous ehold } \\
\text { food security and } \\
\text { resilience }\end{array}$ & $\begin{array}{l}\text { Improved } \\
\text { women's } \\
\text { economic position }\end{array}$ & $\begin{array}{l}\text { Greater women's } \\
\text { participation in the } \\
\text { household and power in } \\
\text { relationships }\end{array}$ & $\begin{array}{c}\text { More gender } \\
\text { equitable attitudes }\end{array}$ & $\begin{array}{r}\text { Greater I } \\
\text { connections; } \\
\text { of poor }\end{array}$ & $\begin{array}{l}\text { vels of social } \\
\text { educed symptoms } \\
\text { nental health }\end{array}$ & $\begin{array}{l}\text { Improved } \\
\text { numeracy and } \\
\text { knowledge of } \\
\text { rights }\end{array}$ \\
\hline \multicolumn{7}{|c|}{ What are the long term impacts? } \\
\hline \multicolumn{7}{|c|}{ Reduction in women's experiences of physical intimate partner violence and depressive symptoms } \\
\hline
\end{tabular}

Fig. 1 Theory of Change: Women for Women International Programme, specifically for IPV reduction

Component 2: Skill Building: the sessions that fall under skill building are delivered through hands-on training and practice over the year-long programme and focus on building basic skills in:

- Numeracy. This is provided for women who need it so that women can learn to count, add/subtract, and use money. All women participants in Afghanistan receive this component.

- Basic business skills. Women learn and practice basic business skills needed for self-employment, group businesses or employment. It covers bookkeeping, selling, planning and marketing their products, and is followed by three sessions on cooperatives looking at the benefits and different types of cooperatives including their structures.

- Vocational skills. WfWI conducts market assessments to identify the best income generation activities for women, given their resources, education and other constraints. Specific training in Afghanistan is focused on animal husbandry, tailoring, gardening and knitting.

Component 3: Resource provision: To complement the informational training and skill building, women 
receive financial support, referrals and opportunities for saving through the 12 months:

- Women receive a monthly conditional cash transfer of US\$10 per month (total received US\$120). There is no stipulation about how women should spend this month. Some women choose to save this money to help them establish their own businesses. Others use it to cover basic needs such as food, clothing and medicine.

- WfWI provides women participants with a range of referral services. A list of referral services is developed. Where women need additional support, they are referred through to services.

- In Afghanistan, WfWI has introduced an adapted version of the Self-Help Group, an informal grouping of women who set up a small 'bank' in which they save together. This is not a compulsory savings programme, but many groups decide to start them as part of the programme.

Component 4: Connections to other women, local women's networks and global supporters: Women go through the programme in classes of 25 and begin the programme with the same group with whom they graduate. This provides a safe space for socially excluded women to learn new skills, share experiences and receive support.

Women for Women International also runs a range of complementary programmes to promote sustainable change and a supportive, enabling environment for women.

Men's engagement activities: Recognising how women's participation and ability to affect change in their lives is often shaped by men in the household and at the community level, WfWI has developed a men's engagement programme (MEP). The goal of the programme is to work with men and male opinion leaders to change gender attitudes and generate an openness to new ideas, such that it is possible to implement the WfWI intervention with women. In Afghanistan, this is a 24 session intervention with male religious and community leaders over three months. The focus of this training is on family rights in Islam. Selected graduates of this programme are then trained to lead "stepdown" discussion groups with men in their local communities to discuss issues around women's rights, multiplying the reach of the initial training. The men discuss topics that affect their communities and their daily lives. The curriculum is underpinned by Islam, quoting verses from the Qur'an to underscore specific aspects of women's rights.

The MEP is being implemented in one of the six villages for the trial as per the practice of WfWI to selectively implement the MEP in selected communities on a case- by-case basis. Through the community assessment process, WfWI find some communities show resistance to WfWI's core programme. WfWI prioritizes those communities for the MEP intervention, as a strategy to reduce resistance and enable support for the programme.

\section{Outcomes}

While traditional evaluations of interventions define one primary outcome, complex interventions, such as this, have increasingly defined multiple primary outcomes that are equally important [19-21]. The primary and secondary outcomes are detailed in Table 1 with questionnaire items used to evaluate outcomes, an example per outcome, and hypothesized direction of change. The trial has three primary outcomes:

- Past year experience of physical IPV amongst currently married women

- Past year experience of severe physical IPV amongst currently married women

- Women's past week depressive symptoms

The secondary outcomes for the study reflect the multiple objectives of the intervention and fall into four categories: economic outcomes; mental health and wellbeing; gender attitudes, and power and violence outcomes.

Secondary economic outcomes are:

- Past four week household food insecurity;

- Financial shock resilience;

- Women's past month earnings; and

- Women's total savings.

Secondary mental health and wellbeing outcomes are:

- Current life satisfaction; and

- Past four week suicidal ideation.

Secondary gender attitudes, and power and violence outcomes are:

- Women's gender attitudes;

- Past year emotional IPV amongst currently married women;

- Perceptions of husband cruelty amongst currently married women;

- Past year mother-in-law and sibling abuse; and

- Perceptions of mother-in-law cruelty amongst currently married women.

\section{Data collection}

Quantitative data were collected through face-to-face structured interviews using paper and pencil by trained 
Table 1 Primary and secondary outcomes for the trial

\begin{tabular}{|c|c|c|}
\hline & Number of items and origins & $\begin{array}{l}\text { Example question and } \\
\text { response categories }\end{array}$ \\
\hline \multicolumn{3}{|l|}{ Primary outcomes } \\
\hline $\begin{array}{l}\text { Past year experience of } \\
\text { physical IPV amongst } \\
\text { currently married women }\end{array}$ & $\begin{array}{l}\text { Five items ask about married } \\
\text { women's experience of } \\
\text { physical IPV. The scale is } \\
\text { based on the WHO's } \\
\text { multi-country study of IPV } \\
\text { [25]. }\end{array}$ & $\begin{array}{l}\text { (Q) In the past } 12 \text { months } \\
\text { how many times has your } \\
\text { husband hit you with a fist } \\
\text { or with something else } \\
\text { which could hurt you? } \\
\text { (A) Never, once, few, many }\end{array}$ \\
\hline $\begin{array}{l}\text { Past year experience of } \\
\text { severe physical IPV } \\
\text { amongst currently married } \\
\text { women }\end{array}$ & $\begin{array}{l}\text { Same scale as above. Severe } \\
\text { physical IPV is defined as } \\
\text { experiencing more than } \\
\text { one item of the five, or } \\
\text { experiencing any one item } \\
\text { more than once, creating a } \\
\text { dichotomous measure } \\
\text { equivalent to more than } \\
\text { once experiencing physical } \\
\text { IPV. }\end{array}$ & $\begin{array}{l}\text { (Q) In the past } 12 \text { months } \\
\text { how many times has your } \\
\text { husband slapped you or } \\
\text { thrown something at you } \\
\text { which could hurt you? } \\
\text { (A) Never, once, few, many }\end{array}$ \\
\hline $\begin{array}{l}\text { Women's past week } \\
\text { depressive symptoms }\end{array}$ & $\begin{array}{l}\text { Depressive symptoms are } \\
\text { assessed using the Center } \\
\text { for Epidemiological Studies } \\
\text { Depression scale (CES-D), } \\
\text { comprising } 20 \text { items asking } \\
\text { about depressive symptoms in } \\
\text { the past week [26]. }\end{array}$ & $\begin{array}{l}\text { (Q) During the past week } \\
\text { I had crying spells } \\
\text { (A) Rarely or none of the } \\
\text { time; some or little of the } \\
\text { time; moderate amount } \\
\text { of time; most or all of the } \\
\text { time }\end{array}$ \\
\hline
\end{tabular}

Secondary outcomes

Household Food Insecurity in past 4 weeks

Financial shock resilience

Women's monthly income

Women's total savings

Life satisfaction

Past four week suicidal ideation
A single item asks about earnings in the past month.

Three items comprising the Household Hunger Scale, developed for global use and comparability [27].

One item asks about ability to mobilise money in an emergency. This measure was developed for use in South Africa, and has been used in Asia.

A single item asks women the total value that they have in savings.

Life satisfaction is assessed using four-items derived from the Satisfaction With Life Scale [28].

This has been used across South Asia [29].

A single item assesses thoughts of suicide in the past month, with a binary response possible.

Scaling Alpha Hypothesized

direction

A positive response to one or

Decrease

more items coded as yes

Two or more items responded

Decrease

to as 'once' or responding to any single item as "few", or "many".

Mean score created; higher

Decrease symptoms

Mean score created; higher

Decrease how often past 4 weeks, food to eat of any kind in your house because of a

lack of money?

(A) Never, Rarely, Sometimes, Often

(Q) If you had an emergency at home and needed 500 Afghani, how easy would you say it would be to find the money?

(A) Very easy, fairly easy, somewhat difficult, very difficult

(Q) Considering all the money you earned from jobs or selling things, how much did you earn last month?

(Q) How much money have you got in savings?

(Q) In most ways my life is close to my ideal (A) Strongly agree, agree, disagree, strongly disagree

Recoded into binary of very or fairly easy and somewhat difficult or very difficult

Mean

Increase

(Q) In the past four weeks, has the thought of ending Binary yes/no

Decrease less satisfied
Mean; higher means your life been in your mind?
(A) Yes, No 
Table 1 Primary and secondary outcomes for the trial (Continued)

\begin{tabular}{|c|c|c|c|c|c|}
\hline & Number of items and origins & $\begin{array}{l}\text { Example question and } \\
\text { response categories }\end{array}$ & Scaling & Alpha & $\begin{array}{l}\text { Hypothesized } \\
\text { direction }\end{array}$ \\
\hline Women's gender attitudes & $\begin{array}{l}\text { This scale was developed } \\
\text { locally from discussions with } \\
\text { Afghan's before being tested } \\
\text { in Pakistan. A series of } 11 \\
\text { questions ask about gender } \\
\text { attitudes that individual } \\
\text { women hold. }\end{array}$ & $\begin{array}{l}\text { (Q) I think it is a good } \\
\text { thing for a young wife in } \\
\text { my family to be beaten to } \\
\text { teach her how to behave } \\
\text { properly } \\
\text { (A) Strongly disagree; } \\
\text { disagree; agree; } \\
\text { strongly agree }\end{array}$ & $\begin{array}{l}\text { Mean score; higher score } \\
\text { indicates less gender } \\
\text { equitable attitudes }\end{array}$ & 0.87 & Decrease \\
\hline $\begin{array}{l}\text { Married women's } \\
\text { participation in household } \\
\text { decision making }\end{array}$ & $\begin{array}{l}\text { Five items are asked about } \\
\text { women's ability to participate } \\
\text { in household decisions, } \\
\text { based on the WHO } \\
\text { Multi-Country Study on } \\
\text { Domestic Violence } \\
\text { [25]. }\end{array}$ & $\begin{array}{l}\text { (Q) In the last three } \\
\text { months, how often your } \\
\text { views been listened to } \\
\text { on matters concerning } \\
\text { the children and their } \\
\text { schooling or work in your } \\
\text { home? } \\
\text { (A) Never; sometimes; } \\
\text { often }\end{array}$ & $\begin{array}{l}\text { Mean score; higher scores } \\
\text { indicate more participation }\end{array}$ & 0.77 & Increase \\
\hline $\begin{array}{l}\text { Past year emotional IPV } \\
\text { amongst currently married } \\
\text { women }\end{array}$ & $\begin{array}{l}\text { Seven items ask about } \\
\text { experiences of emotional } \\
\text { abuse by the husband. }\end{array}$ & $\begin{array}{l}\text { (Q) In the past } 12 \text { months } \\
\text { how many times has your } \\
\text { husband insulted you or } \\
\text { made you feel bad about } \\
\text { yourself? } \\
\text { (A) Never; once; few; many }\end{array}$ & $\begin{array}{l}\text { Mean score; higher score } \\
\text { indicates more emotional } \\
\text { violence }\end{array}$ & & Decrease \\
\hline $\begin{array}{l}\text { Perceptions of husband } \\
\text { cruelty amongst currently } \\
\text { married women }\end{array}$ & $\begin{array}{l}\text { Five items ask about married } \\
\text { women's perceptions of her } \\
\text { husband and his attitudes } \\
\text { and relationship towards her. }\end{array}$ & $\begin{array}{l}\text { (Q) My husband is very } \\
\text { strict and controlling. } \\
\text { (A) Strongly disagree; } \\
\text { disagree; agree; } \\
\text { strongly agree }\end{array}$ & $\begin{array}{l}\text { Mean score: higher scores } \\
\text { indicate more cruelty }\end{array}$ & 0.88 & Decrease \\
\hline $\begin{array}{l}\text { Mother in law and sibling } \\
\text { abuse: }\end{array}$ & $\begin{array}{l}\text { Two items: A single item } \\
\text { assesses whether } \\
\text { mother-in-laws have hit } \\
\text { the woman in the past } \\
12 \text { months and another item } \\
\text { assesses whether siblings } \\
\text { have hit the woman in } \\
\text { the past } 12 \text { months, an } \\
\text { affirmative response to either } \\
\text { item would indicate abuse. }\end{array}$ & $\begin{array}{l}\text { (Q) In the last } 12 \text { months } \\
\text { were you slapped, } \\
\text { hit or beaten by your } \\
\text { mother-in-law? } \\
\text { (A) Never, sometimes, } \\
\text { often }\end{array}$ & $\begin{array}{l}\text { A positive response to one } \\
\text { or both items coded as yes }\end{array}$ & & Decrease \\
\hline $\begin{array}{l}\text { Perceptions of } \\
\text { mother-in-law cruelty. }\end{array}$ & $\begin{array}{l}\text { For married women who } \\
\text { currently live with their } \\
\text { mothers-in-law, six items ask } \\
\text { about their relationship and } \\
\text { the mother-in-law's attitudes } \\
\text { towards her. }\end{array}$ & $\begin{array}{l}\text { (Q) My mother-in-law can } \\
\text { frighten me } \\
\text { (A) Strongly disagree; } \\
\text { disagree; agree; } \\
\text { strongly agree }\end{array}$ & $\begin{array}{l}\text { Mean score: higher scores } \\
\text { indicate more cruelty }\end{array}$ & 0.84 & Decrease \\
\hline
\end{tabular}

female fieldworkers. Questionnaires were translated from English into Dari and Pashto through a process of translation and back translation, and piloted by the fieldwork team. Data collectors conducted individual interviews with women in private locations.

The participant timeline is set out in Fig. 2. Baseline data collection was completed between October 2016 and February 2017. Follow-ups are 12 months and 24 months after baseline.

\section{Assignment of interventions}

Women were individually randomized into the intervention and control arms. Assignment of women into the intervention and control group was done through women drawing coloured balls from an opaque bag or box after enrollment into the study.

While interventions such as this are often randomized at the cluster (village) level into intervention and control arms to avoid contamination [22], pilot work showed that women may mix in public places but did not tend to talk about the types of things covered by the WfWI programme. Given the intensive education content and focus on skills building, we determined that significant contamination was unlikely. Given the levels of insecurity in Afghanistan, this methodology reduced the number of villages where access and research would have to be negotiated, reducing security risks. Randomisation occurred on the day after 


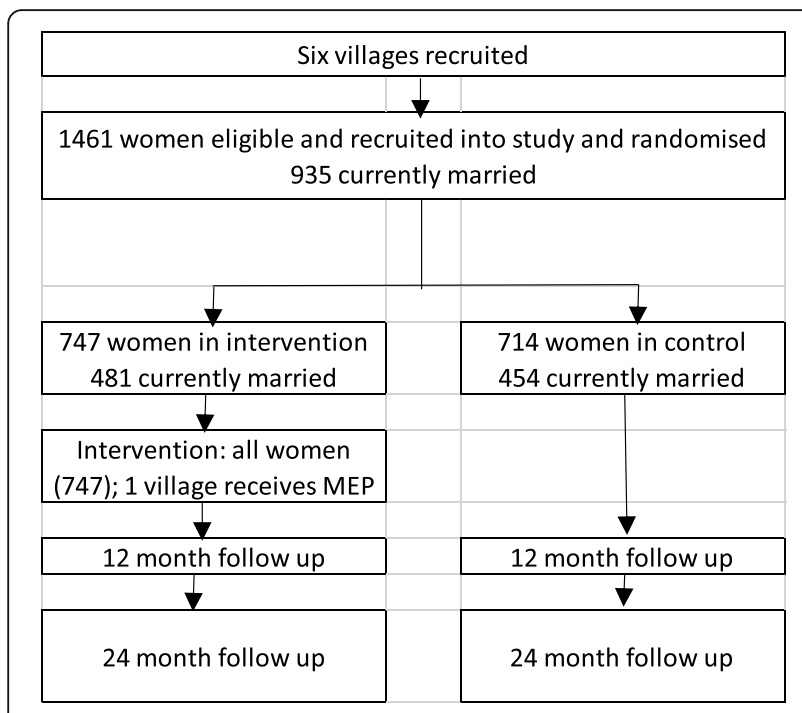

Fig. 2 Evaluation flowchart

recruitment (two villages) or at the time of recruitment (all other villages).

In one village, WfWI ran its men's engagement programme, as detailed above. Villages are not randomized to receive this: it is provided in villages where it is perceived work would be difficult without buy-in from the men in the community.

\section{Data management and analysis}

Questionnaires were double-entered into SPSS, discrepancies between the entered data were identified, and answers were verified through checking the paper questionnaires and corrected. The same process will be undertaken for both follow ups.

The data will be cleaned by the study statistician. One dataset will be compiled for analysis of key variables based on the three data collections: baseline, follow up at the end of the programme (12 months from baseline), and follow up 12 months after programme graduation (24 months from baseline). The data will be described by presenting frequencies for categorical variables and means for scale and sub-scales, with $95 \%$ confidence intervals by study arm.

The main analysis for outcomes of intimate partner violence will be conducted on a sub-set of the sample who are currently married at endline. For depression, it will be conducted on the entire sample. Intention-totreat (ITT) analyses will be conducted. A per protocol analysis will also be conducted as a secondary analysis (i.e. including just those women who attended more than $75 \%$ of WfWI's core programme). Cross tabulation and chi-square tests will be used to determine whether there are differences in demographics between the treatment and control group. The primary analysis will be carried out by fitting Generalized Linear Mixed Models (GLMMs) with a term for treatment arm [23]. For outcomes using scales, the difference in the scores between baseline and 12 months, and baseline and 24 months will be assessed. For each of the scales, a linear mixed model will be fitted with fixed terms for treatment arm. The scores will be directly calculated from the component items, while the scales will combine the items using weights determined by carrying out a principal component analysis on the items at baseline, and using the loadings for the first principal component as the weight for each item. These analyses will firstly be carried out on the ITT population and then repeated for the per protocol population.

\section{Ethics}

The research is structured according to the WHO's guidance on doing research around violence against women [24]. The trial has been designed to ensure that the project does not expose potential of harm to participants and to respond to any emotional or psychological harm that may result from the questions that will be asked in this study.

If participants become distressed during the research or the intervention, the team has in place a series of referral mechanisms to appropriate support. Given the challenges of working Afghanistan and limited availability of services, specific referrals vary from village to village but include government health services and NGOs specialising in working with women survivors of violence.

Participants provided thumbprints as informed consent to participate in the study given the incredibly low levels of literacy. Personal data will be stored separately from data, and no identifying information is collected on the questionnaires. Unique identifying codes link questionnaires with participant information for tracking purposes at 12 and 24 months.

Ethical approval for the study was given by the South African Medical Research Council (EC034-11-2015) and the Afghan Ministry of Public Health (399302). Throughout the study, any harm to the participants in the form of adverse events, serious adverse events, and participant deaths will be reported to ethics committees.

\section{Discussion \\ Implementation}

In total, six villages in five districts across two provinces were identified and agreed to participate in the study. A seventh village was approached but declined to be part of the study due to the randomisation process. A total of 1461 women were recruited and randomised into the study at baseline. Of the total recruited, 935 were currently married at baseline. 
There are some important demographic differences between the districts sampled. In Kalakan district in Kabul, community members are predominantly Tajik with a small proportion of Pashtuns. In Nangarhar province (in both districts), community members are predominantly Pashtun with a small proportion of Tajiks. In Dashte Barchi district of Kabul province, community members are predominantly Hazara.

\section{Challenges}

The research team faced unanticipated challenges in recruitment and randomization. Women were incredibly keen to be involved in the intervention, which posed challenges that the field team resolved through the development of additional processes to screen and manage participants.

The high demand to participate in the study and intervention led to very large numbers of women assembling for recruitment. This meant that adequately briefing them on the programme and study procedures in one large group was difficult and further complicated by women who continued to arrive throughout the day. In addition, crowd control was difficult with large numbers of women assembling for recruitment (up to several hundred at any time). As the day progressed, women became unsettled and in many cases aggressive due to fears of not entering the recruitment site before the recruitment quota had been reached. This often led to women finding ways to enter the recruitment location, for instance through windows or by pushing through doors, at which point recruitment became difficult and in some cases had to be terminated and continued on a different day.

Screening women for eligibility was also challenging. The majority of women did not have any form of identification proving their age (which is common in Afghanistan); therefore, much older women and younger girls attempted to be recruited despite the age criteria. Although attempts were made to make a judgment on age, this was often difficult. Furthermore, some women deemed ineligible to participate would return later in the day, or on the following day, often dressed in burqas or different clothing, or with someone else's identity documents, in an attempt to pass the screening process. In addition, male family members occasionally came to the registration sessions, angry that the women in their families could not, or had not, been registered.

There were also a number of challenges in the randomization procedures. Much like for recruitment, managing large crowds was highly challenging and escalated by women sometimes being upset or angry by not being randomised into the intervention. At times, the randomization process had to be terminated and continued on another day due to concerns about the safety of
WfWI and research staff. After several randomizations, it became evident that women had explained to other women what each colour signified, and some women would attempt to look into the box before drawing a ball to enable their selection of a blue ball. In these cases, women were asked to draw again.

To overcome these challenges, a number of procedures were implemented and these were modified throughout the recruitment to minimize risk and ensure study integrity. First, women were briefed in smaller groups of 20 (rather than one large group). Second, registration and randomization was conducted on the same day and quickly to minimize the number of women at the site. Third, only small numbers of women were let into the sites at a time with adequate staff at each point to monitor women's entry and departure from sites. Finally, a permanent marker was used to mark women's wrists to ensure they could not be registered twice in the study. These procedures eased the process and ensured the project could adhere to the protocol. At times, however, when the process became too challenging, the team stopped work for the day and returned the following day to maintain quality of process.

In one community, the research manager received a phone call from a husband of one of the study participants. The husband was asking questions about why the intervention was asking women about family violence. It became apparent that men in this community had found out about the questionnaire and the topics, including IPV, and were talking about it amongst themselves. The team paused fieldwork in this community and WfWI called a community meeting. The District Governor attended, with some men from the communities, and it was reiterated what the intervention was and hoped to achieve, reiterated that there were some questions about family conflict as these were about women's health, but these were confidential and were part of a much broader set of questions. Following the meeting, the community agreed to allow the study to continue with no further similar issues.

\section{Baseline comparison}

Despite the challenges of implementing research in a complex environment, where there was high demand for inclusion in the study and intervention, the baseline socio-demographic data shows comparability between study arms, showing randomization was effective (Table 2). There were no significant differences between study arms, either amongst all women $(n=1461)$, or amongst married women only $(n=935)$.

The average age of the respondents was just under 30 (29.3 intervention, 29.3 control). In both arms, just under two-thirds were currently married, and just under 
Table 2 Socio-demographic information by study arm

\begin{tabular}{|c|c|c|c|c|c|c|c|c|c|c|c|c|}
\hline & \multicolumn{6}{|c|}{ All women } & \multicolumn{6}{|c|}{ Currently married women only } \\
\hline & \multirow[t]{2}{*}{ Total } & \multicolumn{2}{|c|}{ Intervention } & \multicolumn{2}{|c|}{ Control } & \multirow[t]{2}{*}{$p$-value } & \multirow[t]{2}{*}{ Total } & \multicolumn{2}{|c|}{ Intervention } & \multicolumn{2}{|c|}{ Control } & \multirow[t]{2}{*}{$p$-value } \\
\hline & & mean & $(95 \% \mathrm{Cl})$ & mean & $(95 \%$ Cl) & & & mean & $(95 \% \mathrm{Cl})$ & mean & $(95 \%$ Cl) & \\
\hline \multirow[t]{2}{*}{ Age } & 1461 & 29.3 & $28.7-29.9$ & 29.3 & $28.6-30.0$ & 0.99 & 935 & 32.4 & $31.8-33.0$ & 32.4 & $31.7-33.1$ & 0.97 \\
\hline & & $n$ & (\%) & $n$ & (\%) & & & $n$ & (\%) & $n$ & (\%) & \\
\hline \multicolumn{13}{|l|}{ Relationship Status } \\
\hline Currently married & 935 & 481 & 64.4 & 454 & 63.6 & & & & & & & \\
\hline Previously married & 98 & 48 & 6.4 & 50 & 7.0 & & & & & & & \\
\hline Never married & 428 & 218 & 29.4 & 210 & 29.4 & 0.89 & & & & & & \\
\hline \multicolumn{13}{|l|}{ Education } \\
\hline None & 1129 & 581 & 77.8 & 548 & 76.8 & & 781 & 408 & 84.8 & 373 & 82.2 & \\
\hline Madrasa & 92 & 52 & 7.0 & 40 & 5.6 & & 47 & 25 & 5.2 & 22 & 4.9 & \\
\hline Primary schooling & 147 & 74 & 10.1 & 73 & 10.2 & & 75 & 36 & 7.5 & 39 & 8.6 & \\
\hline Secondary schooling & 93 & 40 & 6.4 & 53 & 7.4 & 0.31 & 32 & 12 & 2.5 & 20 & 4.4 & 0.38 \\
\hline \multicolumn{13}{|c|}{ Borrowing food or money in past month because of not having enough } \\
\hline No & 437 & 215 & 28.9 & 222 & 31.1 & & 281 & 141 & 29.4 & 140 & 30.9 & \\
\hline Yes & 1021 & 530 & 71.1 & 491 & 68.9 & 0.34 & 651 & 338 & 70.6 & 313 & 69.1 & 0.63 \\
\hline
\end{tabular}

$30 \%$ had never been married. Education levels in the whole sample were low: three-quarters of women had never received any formal education (77.8\% intervention, $76.8 \%$ control). Of the quarter who had received education, around $6 \%$ had been to a Madrasa, $10 \%$ had received some form of primary school education, and $6.4 \%$ (intervention) and 7.4\% (control) had some level of secondary education. There were also high levels of poverty, with approximately $70 \%$ of the sample reporting borrowing food or money in the past month because they did not have enough.

There was similar balance amongst women who were currently married by study arm. Currently married women were slightly older than the entire sample (both married and unmarried) at about 32 years and this was balanced across arms. The overwhelming majority reported not receiving any schooling ( $84.8 \%$ intervention, $82.2 \%$ control). Only about $5 \%$ in either arm of married women had been to a Madrasa only, while about $8 \%$ had received some primary education and around 3\% some secondary education. There were no significant differences between arms for married women in terms of borrowing money because of hunger, with around $70 \%$ reporting this in each arm.

\section{Limitations}

The study has a number of limitations, primarily linked to the wider challenges of operating in a conflict/postconflict setting. Due to the challenges with recruitment and randomization at the start of the process, there are slightly more participants in the intervention arm $(n=$ 747) compared to the control arm $(n=714)$. Despite this, the randomization was effective in achieving balance in socio-demographic measures across arms. The decision to randomize at the individual level, rather than the cluster level may have an impact. The concern remains that there could be some information diffusion from those in the intervention to those in the control group. WfWI had previously worked in two of the villages so there is some possibility that there could already be spillover effects in these villages, which may impact results.

We were advised not to include questions which might be considered offensive or very embarrassing for women. Therefore, we did not ask about sexual violence even though sexual violence in prevalent in Afghanistan [15] and measures of IPV include sexual violence in other settings. The low level of past-year sexual IPV reported in the Afghan DHS somewhat supports our decision, as it suggests that the notion was either hard to interpret culturally or particularly embarrassing for women to report.

Finally, while the study is currently operating, the ongoing security challenges of working in Afghanistan remain paramount. Depending on the wider political situation, this may reduce programming intensity and also lead to challenges around follow-up of participants.

\section{Conclusion}

IPV remains a pressing concern in conflict, post-conflict and humanitarian emergencies, often eclipsing forms of state and non-partner sexual violence $[1,2]$. The lack of well-evaluated interventions to prevent IPV is a major challenge in developing a strong evidence base on 
preventing IPV in these contexts. Despite the challenges of operating and undertaking research in complex settings, the implementation of this study shows that there is a significant desire for interventions and women's education and empowerment in these contexts. The WfWI intervention trial in Afghanistan will provide important evidence on the scope and scale of IPV, as well as on the potential of economic and gender empowerment interventions to work effectively in complex settings.

\section{Endnotes}

${ }^{1}$ Bride price (walwar in Pashto and sherbaha in Dari) should not be confused with the dowry (mahr), the former which is a sum of money paid to the father or other male family member of a bride, and the latter a sum of money paid directly to the bride to provide economic security in case her husband dies or divorces here. Although mahr is enshrined in Islamic Sharia law, it is rarely implemented in Afghanistan with bride price being the most common practice.

${ }^{2}$ This has been well documented by human rights organisations, for example: UN SCR 1325 Implementation in Afghanistan (AWN, 2011) http://www.awn-af.net/ index.php/cms/content/501; AWN Annual 2nd Report on CEDAW in Afghanistan (AWN, June 2016); http:// www.awn-af.net/index.php/cms/content/501; https:// www.hrw.org/news/2016/05/25/afghanistan-end-moralcrimes-charges-virginity-tests; Their lives on the line: women human rights defenders under attack in Afghanistan (Amnesty International, April 2015) https:// www.amnesty.org/en/documents/asa11/1279/2015/en/

${ }^{3}$ See: www.whatworks.co.za

\section{Acknowledgements}

We wish to acknowledge the fieldwork team and facilitators involved in the study, as well as the participants for sharing their data.

\section{Funding}

This trial is funded through the What Works To Prevent Violence? A Global Programme on Violence Against Women and Girls (VAWG) funded by the UK Government's Department for International Development (DFID). ${ }^{3}$ However, the views expressed do not necessarily reflect the department's official policies and the funders had no role in study design; collection, management, analysis, and interpretation of data; writing of the report; and the decision to submit the paper for publication. Funding was also received from the South African Medical Research Council for their staff members.

\section{Availability of data and materials}

The datasets generated and/or analysed during the current study will be made publicly available as per DfID guidelines one year after completion of data collection.

\section{Authors' contributions}

RJ, CM obtained funding for the research. RJ, AG, EC, JC, MS, FM, AM, CM, FK have contributed to the design of the study. The first draft of this manuscript was produced by RJ, AG, JC, CMJ, CM, FK, AM, and all other authors have reviewed, edited and approved the final version.

\section{Ethics approval and consent to participate}

The study received ethical approval from the South African Medical Research Council (EC034-11-2015) and the Afghan Ministry of Health (399302). All participants provided informed consent, with thumb prints replacing signatures given the low levels of literacy, to participate in the study.

Consent for publication

Not applicable.

\section{Competing interests}

The authors declare that they have no competing interests.

\section{Publisher's Note}

Springer Nature remains neutral with regard to jurisdictional claims in published maps and institutional affiliations.

\section{Author details}

${ }^{1}$ Gender and Health Research Unit, South African Medical Research Council, Pretoria, South Africa. ${ }^{2}$ Women for Women International, Kabul, Afghanistan. ${ }^{3}$ Women for Women International, London, UK. ${ }^{4}$ Eureka, Kabul, Afghanistan.

Received: 19 September 2017 Accepted: 3 January 2018

Published online: 22 January 2018

\section{References}

1. Hossain M, Zimmerman C, Watts C. Preventing violence against women and girls in conflict. Lancet. 2014:383(9934):2021-2.

2. Stark L, Ager A. A systematic review of prevalence studies of genderbased violence in complex emergencies. Trauma, Violence, \& Abuse. 2011;12(3):127-34

3. Vinck P, Pham P. Association of exposure to intimate-partner physical violence and potentially traumatic war-related events with mental health in Liberia. Soc Sci Med. 2013;77:41-9.

4. Sriskandarajah V, Neuner F, Catani C. Predictors of violence against children in Tamil families in northern Sri Lanka. Soc Sci Med. 2015;146:257-65.

5. Hossain M, Zimmerman C, Kiss L, Kone D, Bakayoko-Topolska M, Manan DKA Lehmann H, Watts C. Men's and women's experiences of violence and traumatic events in rural Côte d'lvoire before, during and after a period of armed. Conflict. 2014;4:e003644.

6. Saile R, Ertla V, Neunera F, Catani C. Does war contribute to family violence against children? Findings from a two-generational multi-informant study in Northern Uganda. Child Abuse Negl. 2014;38:135-46.

7. Clark CJ, Everson-Rose SA, Suglia SF, Btoush R, Alonso A, Haj-Yahia M. Association between exposure to political violence and intimate partner violence in the occupied Palestinian territory: a crosssectional study. Lancet. 2010;375:310-6

8 . Jewkes R, Jama-Shai N, Sikweyiya Y. Enduring impact of conflict on mental health and gender-based violence perpetration in Bougainville, Papua New Guinea: a cross-sectional study. Plos One. under review

9. Green EP, Blattman C, Jamison J, Annan J. Women's entrepreneurship and intimate partner violence: a cluster randomized trial of microenterprise assistance and partner participation in post-conflict Uganda (SSM-D-1401580R1). Soc Sci Med. 2015:133:177-88.

10. Beath A, Christia F, Enikolopov R. Empowering women through development aid: evidence from a field experiment in Afghanistan. Am Polit Sci Rev. 2013;107(03):540-57.

11. Gupta J, Falb KL, Lehmann H, Kpebo D, Xuan Z, Hossain M, Zimmerman C, Watts C, Annan J. Gender norms and economic empowerment intervention to reduce intimate partner violence against women in rural cote d'Ivoire: a randomized controlled pilot study. BMC Int Health Hum Rights. 2013;13(1):46

12. Ellsberg M, Arango DJ, Morton M, Gennari F, Kiplesund S, Contreras M, Watts C. Prevention of violence against women and girls: what does the evidence say? Lancet. 2015;385(9977):1555-66.

13. Gibbs A, Kerr-Wilson A, Jacobson J. A Global Comprehensive review of economic interventions to prevent intimate partner violence and HIV risk behaviours. Glob Health Action. 2017:10(Sup2):1-15.

14. Central Statistics Organization. Afghanistan Living Conditions Survey 2013-14. National Risk and Vulnerability Assessment. In. Kabul: Central Statistics Organisation; 2016

15. Central Statistics Organization. Afghanistan Demographic and Health Survey 2015. In Kabul: Central Statistics Organisation; 2017

16. Nijhowne D, Oates L. Living with violence: a National Report on domestic abuse in Afghanistan. In. Kabul: Global Rights - Partners for Justice; 2008. 
17. Chan A-W, Tetzlaff JM, Gøtzsche PC, Altman DG, Mann H, Berlin JA, Dickersin K, Hróbjartsson A, Schulz KF, Parulekar WR. SPIRIT 2013 explanation and elaboration: guidance for protocols of clinical trials. BMJ. 2013;346:e7586.

18. Jewkes R, Nduna M, Levin J, Jama N, Dunkle K, Puren A, Durvury N. Impact of stepping stones on incidence of HIV, HSV-2 and sexual behaviour in rural South Africa: cluster randomised controlled trial. Br Med J. 2008;337:a506.

19. Pronyk P, Hargreaves JR, Kim JC, et al. Effect of a structural intervention for the prevention of intimate partner violence and HIV in rural South Africa: a cluster randomised trial. Lancet. 2006;368:1973-83.

20. Wagman J, Gray RH, Campbell JC, Thoma M, Ndyanabo A, Ssekasanvu J, Nalugoda F, Kagaayi J, Nakigozi G, Serwadda D, et al. Effectiveness of an integrated intimate partner violence and HIV prevention intervention in Rakai, Uganda: analysis of an intervention in an existing cluster randomised cohort. Lancet Glob Health. 2015;3(1):e23-33.

21. Hegarty K, O'Doherty L, Taft A, Chondros P, Brown S, Valpied J, Astbury J, Tacket A, Gold L, Feder G, et al. Effect of screening and brief counselling for abused women on quality of life, safety planning and mental health: a primary care cluster randomised controlled trial (weave). Lancet. 2013; 382(9888):249-58. https://doi.org/10.1016/50140-6736(13)60052-5.

22. Hayes R, Moulton L. Cluster Randomised Trials. London: Taylor and Francis; 2009.

23. Wears R. Advanced statistics: statistical methods for analyzing cluster and cluster-randomized data. Acad Emerg Med. 2008:9(4):330-41.

24. Ellsberg M, Heise L. Putting women's safety first: ethical and safety recommendations for research on domestic violence against women. In.: Geneva, Switzerland: World Health Organization; 1999.

25. Garcia-Moreno C, Jansen HAFM, Ellsberg M, Heise L, \& Watts CH. Prevalence of intimate partner violence: findings from the WHO multi-country study on women's health and domestic violence. Lancet. 2006:368(9543):1260-69.

26. Radloff $L$. The CES-D scale a self-report depression scale for research in the general population. Appl Psychol Meas. 1977;(3):385-401.

27. Coates J, Swindale A. \& Bilinsky P. Household Food Insecurity Access Scale (HFIAS) for measurement of food access: indicator guide. Washington, DC Food and Nutrition Technical Assistance Project, Academy for Educational Development: 2007

28. Diener ED, Emmons R, Larsen R, \& Griffin, S. The satisfaction with life scale. J Pers Assess. 1985:49(1):71-75

29. Fulu E, Jewkes R, Roselli T, Garcia-Moreno, C. \& UN Multi-Country Cross Sectional Study on Men Violence, Prevalence of and factors associated with male perpetration of intimate partner violence: findings from the UN Multi-country Cross-sectional Study on Men and Violence in Asia and the Pacific. Lancet Glob Health. 2013;1(4):e187-e207

\section{Submit your next manuscript to BioMed Central and we will help you at every step:}

- We accept pre-submission inquiries

- Our selector tool helps you to find the most relevant journal

- We provide round the clock customer support

- Convenient online submission

- Thorough peer review

- Inclusion in PubMed and all major indexing services

- Maximum visibility for your research

Submit your manuscript at www.biomedcentral.com/submit 